\title{
Critical Discourse Analysis Fairclough on The Content of Game FF and PUBG in The Media Tiktok
}

\author{
Analisis Wacana Kritis Fairclough pada Konten Game \\ FF dan PUBG di Media Tiktok
}

\author{
Bayu Aji Sastra Jendra \\ Universitas Jember \\ E-mail: bayujendra@gmail.com
}

\begin{abstract}
A media that can connect every human being in all corners of the world so that it creates a new world, namely the online or virtual world. From here it is very possible for an exchange of ideology to occur through a discourse carried by an individual or a group which could be through a content channeled through a medium such as Tiktok for example. The purpose of this research is to analyze critical discourse on the contents in Tiktok media related to FF and PUBG games. The research method used is qualitative with a critical paradigm as a foundation in the point of view used. The theory used in this study is Norman Fairclough's critical discourse analysis with descriptive analysis, interpretation and explanation methods. The result of this research is the discovery of differences in discourse that are raised in each content in Tiktok media, where each content framing is carried out with the characteristics of each individual, so that the meaning of the discourse raised can be known by the general public.
\end{abstract}

Keywords: Critical Discourse Analysis, Media Tiktok, Game FF and PUBG

\begin{abstract}
ABSTRAK
Sebuah media yang bisa menghubungkan setiap manusia yang ada di seluruh penjuru dunia sehingga memunculkan sebuah dunia baru yaitu dunia online atau maya. Dari sini sangat memungkinkan sebuah pertukaran ideologi terjadi melalui sebuah wacana-wacana yang dibawa oleh seorang individu ataupun kelompok yang bisa jadi melalui sebuah konten yang disalurkan melalui sebuah media seperti Tiktok contohnya. Tujuan dari penelitian ini analisis wacana kritis terhadap konten-konten yang ada di media tiktok yang bersangkutan dengan game $\mathrm{FF}$ dan PUBG. Metode penelitian yang digunakan adalah kualitatif dengan paradigma kritis sebagai tumpuan dalam sudut pandang yang digunakan. Teori yang digunakan dalam penelitian ini adalah analisis wacana kritis Norman Fairclough dengan metode analisis deskripsi, interpretasi, dan eksplanasi. Hasil penelitian ini adalah ditemukannya perbedaan wacana yang diangkat di dalam setiap konten di media tiktok, yang mana setiap pembingkaian konten dilakukan dengan ciri khas masing-masing individu, supaya makna dari wacana yang diangkat dapat diketahui oleh khayalak umum.
\end{abstract}

Kata Kunci: Analisis Wacana Kritis, Media tiktok, Game FF dan PUBG 


\section{PENDAHULUAN}

Perkembangan teknologi semakin hari kian tidak dapat dipungkiri lagi bahwa kehidupan mulai berpindah kepada yang biasa disebut dengan dunia maya. Hal ini terjadi karena manusia yang sudah mengenal teknologi informasi, internet serta jaringan/network sekarang mulai menjalani kehidupannya sebagian besar di dunia maya, seperti komunikasi dengan kawan atau keluarga menggunakan Media sosial seperti Instagram dan Whatsapps, kemudian mencari hiburan ataupun informasi dapat juga menggunakan dunia maya yaitu melalui pencarian Google.

Henry Jenkins seorang Profesor dikenal dengan teorinya Media Convergence, menyebutkan perihal cyberculture yang memiliki arti penyatuan kultur antara Personal Computer (PC), Telepon, Internet, dan Multimedia di dalam sebuah sistem komunikasi yang terintegrasi (Pramod K Nayar, 2010), dari sini dapat menunjukan bahwa mediamedia saling terintegrasi dengan sebuah jaringan/network dengan internet membuat manusia saling bisa berkomunikasi dan berinteraksi sehingga mampu memunculkan sistem kehidupan baru (budaya baru) yaitu dunia maya.

Ketika melihat situasi masa pandemi Covid-19 ini hampir seluruh aktivitas manusia berpindah ke dunia maya, mulai dari pekerjaan, pendidikan dan hiburan, dikarenakan aktivitas di dunia nyata dibatasi untuk mencegah penyebaran dari virus tersebut. Hal ini, semakin membuat kehidupan di dunia maya semakin padat dikarenakan seluruh mediamedia daring mulai dimasuki oleh manusia semua kalangan dari kecil sampai manula. Salah satunya adalah media hiburan tiktok berdasarkan informasi dari cnbcindonesia mengenai tiktok adalah laporan dari pihak bytedance selaku pihak yang meluncurkan aplikasi tiktok memberikan informasi perihal pengguna aktif per-bulannya (monthly active users) sejak tahun 2016 sampai Juli 2020 mencapai angka 689,17 juta user, padahal di tahun 2018 Januari pengguna aktif Tiktok hanya 55 juta user dan mulai meningkat di tahun 2019 akhir mencapai angka 507 juta user. (CNBC Indonesia, 2020)

Tiktok sendiri merupakan media hiburan yang berbasis daring, dimana isinya berupa sistem jaringan sosial dan platform audiomusik. Jadi, tiktok memberikan kepada pengguna/user sebuah kebebasan untuk membuat video dan musik pendek mereka sendiri, lalu dari situ juga ditampilkan di beranda sehingga orang lain yang sama-sama menggunakan aplikasi Tiktok dapat melihat karya mereka serta apabila tertarik dengan karya tersebut bisa langsung difollow, akhirnya memunculkan pertemanan baru atau bisa disebut jaringan sosial tadi. Tiktok juga mampu menghasilkan uang apabila kontenkonten video/musik pendek yang mereka buat banyak yang melihat serta banyak yang mem-follow akun dari orang yang membuat konten tersebut.

Sebenarnya media daring memiliki banyak jenisnya serta keberfungsian contohnya adalah sosial media seperti Instagram, Facebook, dan twitter berfungsi untuk menemukan relasi/jaringan baru mulai dari pertemanan ataupun rekanan kerja. Selanjutnya adalah situs media daring berbentuk website misal seperti CNN Indonesia mampu memberikan sebuah informasi seperti berita baik itu yang aktual ataupun berita lama yang masih layak kaji. Lalu, tentu kita tidak bisa menafikkan media daring yang berisi hiburan selain tiktok, yaitu Youtube, Likee, Snack Video yang mana fitur yang diberikan hampir sama dengan tiktok, serta mampu menghasilkan uang juga, meskipun yang sedang merajai atau berada diatas adalah Tiktok dengan berbagai fitur yang diberikan.

Selain media-media hiburan yang disebutkan terdapat juga hiburan yang paling diminati dikalangan anak muda zaman sekarang, yaitu game. Game online merupakan sebuah game yang dimainkan di dalam dunia maya atau bisa dikatakan menggunakan jaringan internet, sedangkan menurut Andri Dkk dalam bukunya yang berjudul jangan suka game online, game online adalah sebuah game yang hanya bisa dimainkan lewat 
perangkat dimana pernagkat tersebut harus tersambung dengan jaringan internet.(Andri Arif Kustiawan, Andy Widhiya Bayu Utomo, 2019)

Game memiliki banyak jenisnya ada yang berbentuk Petualangan, ada juga yang berbentuk arena/battleroyal. Game dapat dibedakan melalui piranti yang mereka gunakan untuk bermain yaitu menggunakan HP, lalu ada yang menggunakan PC, serta menggunakan Console Playstation/X-Box. Sekarang game yang sedang naik daun dan dimainkan oleh banyak orang adalah game yang ada di HP atau biasa disebut game mobile, yaitu Free Fire dan PlayerUknown's Battlegrounds (PUBG), kedua game ini merupakan game yang berbentuk Tembak-tembakan (Battleroyal). Sejarah dari kedua game besar ini berbeda dan memang developernya pun berbeda, namun ini hari kedua game inilah yang sedang berada dipuncak dari game Battlefield. Hal tersebut dapat terlihat dari grafik yang ditampilkan Playstore perihal game yang terlaris selalu terlihat 2 game battleroyal ini selalu di papan atas. Hal ini menunjukkan bahwa banyak yang berminat memainkannya. Apalagi disaat pandemi Covid-19 seperti sekarang ini akan membuat banyak game dimainkan dikarenakan aktivitas di luar rumah seperti olahraga dikurangi jadi manusia lebih banyak menghabiskan waktunya dirumah sehingga maklum apabila kebanyakan waktu luangnya digunakan untuk memainkan game-game online seperti FF dan PUBG.

Namun, sebuah hal yang terlalu sering dilakukan pasti membawa dampak yang buruk bagi penggunanya, tidak luput dari para pemain game itu sendiri. Banyak dampak buruk yang terjadi terhadap pemain game yang terlalu berlebihan dalam memainkan gamenya baik itu Free Fire ataupun PUBG. Dampak buruknya seperti kelelahan mata dan anggota tubuh yang lain, lalu kelelahan jiwa dikarenakan mental terus di tekan untuk memenangkan permainan, selanjutnya menyebabkan pengurangan materi yang lumayan besar seperti harus membeli paketan setiap bulannya kadang tidak sampai sebulan, lalu juga harus pergi ke daerah WI-FI yang biasanya ada warung sehingga juga harus membeli jajan ataupun minuman disitu sembari memakai fasilitas WI-FInya, belum lagi kalau semisal Handphone yang jadul tidak memadai untuk memainkan gamegame seperti diatas maka dia juga harus mengeluarkan uang lagi untuk membeli HP baru sehingga jelas terlihat kehilangan materi dapat dipastikan.

Terdapat sebuah penelitian dimana membahas mengenai dampak dari kecanduan bermain game online, penelitian dari Mimi Ulfa dengan target para remaja di daerah Pekanbaru dari penelitian tersebut hendak dicari adakah pengaruh dari kecanduan game pada prilaku remaja yang mengarahkan baik ke positif ataupun negatif. Berdasarkan data yang di dapatkan ditemukan hasil analisis uji hipotesa dengan nilai $\mathrm{t}$ hitung $>$ t table $(4032.276>0.195)$ dimana hipotesa yang diajukan yaitu ada pengaruh antara kencanduan game online terhadap prilaku remaja. (Ulfa, 2017).

Meskipun pembahasan diatas juga masih memiliki banyak kontradiksi yaitu disaat ada yang mengatakan bahwa bermain game online hanya akan membawa dampak negatif yang besar, dengan pendapat lain yang mengatakan bahwa game online dapat memberikan manfaat lebih daripada dampak negatifnya asalkan dengan penekanan di beberapa hal. Seperti narasi yang disampaikan dalam buku Gagasan pemuda untuk Jakarta, yaitu dengan peningkatan kualitas diri mampu memberikan sebuah tameng untuk anak muda dalam kencanduan game online dengan sebuah pembuktian dari serangkain uji coba yang dilakukan dengan subjek anak muda yang sedang mengalami kencanduan game online (penyakit mental).(FIM Jakarta, 2020) Berdasarkan pendapat diatas dapat diambil garis besar bahwa memainkan game tidak hanya akan memberikan dampak buruk asalkan memberikan sebuah kunci supaya dampak buruknya bisa ditekan yaitu dengan peningkatan kualitas diri subjek pemain game (anak-anak ataupun remaja). 
Bahkan di dalam buku karya andi dkk juga disebutkan beberapa kelebihan dari game online, yaitu sebagai berikut. 1. Meningkatkan kemampuan berkonsentrasi karena di setiap level game yang di capai memiliki Batasan-batasan yang mana memiliki tingkat konsentrasi yang berbeda., 2. Meningkatkan kemampuan motorik, artinya dengan pola permainan yang ada dapat menyebabkan data yang masuk kedalam mata harus dikoordinasikan ke otak dengan cepat supaya tangan dapat langsung meresponya dan hal tersebut terjadi terus menerus sehingga kemampuan motorik terasah., 3. Meningkatkan kemampuan berbahasa inggris, karena hampir seluruh game online yang disediakan/diciptakan menggunakan Bahasa internasional yaitu Bahasa inggris, hal tersebut dilakukan oleh pengembang game karena penikmat dari game yang diciptakan tidak hanya di negara Indonesia saja melainkan di seluruh dunia sehingga diperlukan Bahasa internasional di dalamnya. (Andri Arif Kustiawan, S.Pd., M. Or. , Andy Widhiya Bayu Utomo, S.Pd., 2019). Masih banyak lagi kelebihan yang di ada di dalam buku tersebut namun, hanya dengan 3 contoh itu saja sudah bisa menyakinkan kita bahwa game online tidak hanya membawa dampak negatif, melainkan banya juga dampak positif yang mana mampu meningkatkan kapasitas diri anak.

Namun keadaan yang ada di lapangan mengenai pemain game FF dan PUBG seringkali mengelurkan kata-kata buruk ketika bermain ataupun saat di dunia nyata. Hal tersebut terjadi tentu karena dampak negative dari game itu sendiri yaitu saat pertemuan antara orang-orang yang memiliki karakteristik yang berbeda kadang ditemukan ketidakcocokan dan akhirnya marah dan mengeluarkan kata kotor, dikarenakan sering dimainkan akhirnya membawa kebiasaan itu di dunia nyata.

Dikarenakan kedua game ini memiliki banyak penikmat akhirnya menjadi viral serta banyak dibicarakan di media-media online seperti Instagram (IG), Facebook (FB) dan bahkan tiktok, namun buruknya adalah konten-konten yang dikeluarkan disangkutpautkan dengan game tersebut, yang mana konten-konten tersebut lebih mengarah ke hal-hal yang negatif yaitu, berisi ejekan dan hinaan terhadap salah satu game baik itu Free Fire ataupun PUBG sehingga menimbulkan pertengkaran ataupun perdebatan antara pengguna salah satu game diatas. Konten-konten yang berisi hal demikian bisa dikatagorikan sebagai ujaran kebencian, karena sesuai dengan pendapat dari Raphael Cohen-Almagor dalam buku Hoax dan Hate Speech di dunia Maya yaitu, ujaran kebencian merupakan ujaran yang memiliki motif jahat yang mengkespresikan diskriminasi, intimidasi, penolakan, praduga orang perseorangan atau kelompok orang yang berkaitan dengan isu gender, ras, agama, etnik, warna, negara asal, ketidakmampuan atau orientasi seksual.(Mac Aditiawarman, 2019). Terlihat bahwa ejekan dan hinaan juga merupakan ujaran kebencian karena memiliki motif jahat seperti menjatuhkan dan menyudutkan salah satu pihak.

Keadaan yang lebih memprihatinkan lagi orang-orang diluar pengguna dari kedua gam tersebut ikut terpangaruh oleh pertengkaran yang ada antara pemain game free fire dan PUBG, terkadang kehadiran mereka hanya memperkeruh keadaan karena ikutikutan mengeluarkan ujaran-ujaran kebencian tanpa ada tujuan yang jelas, atau bahkan ikut meramaikan jagat media sosial dengan perseteruan yang terjadi melalui konten yang dibuat untuk menjelekkan keduanya atau salah satu saja. Prilaku demikian selaras dengan hasil penelitian yang dilakukan oleh Dedi Rianto mengenai prilaku pengguna media sosial dengan informasi hoax yang tersebar, hasil penelitian tersebut adalah ditemukannya prilaku dari pengguna media sosial cukup beragam dalam merespon informasi hoax yang tersebar sesuai dengan latar belakang dari pengguna juga, mereka menyebarkan informasi demikian dengan tahu konsekuensinya ada beberapa alasan yang menyebabkan mereka tetap menyebarluaskannya informasi tersebut yaitu supaya hoax tersebut mempengaruhi pendapat dan prilaku yang lain, lalu alasan paling utama 
supaya mereka bisa menjadi pengguna media sosial yang terkenal. (Rahadi, 2017). Garis kesimpulannya adalah kemungkinan besar para non-pemain yang ikut-ikutan dalam menyebarkan ujaran kebencian yang terjadi adalah untuk menjadi terkenal, atau kalau tidak mereka hanya ingin perseteruan yang terjadi semakin besar diantara para pemain dengan cara mengarahkan ujaran-ujaran kebencianya di media luas.

Berdasarkan keterangan diatas dapat ditangkap informasi bahwa sebuah media dapat dikatakan mempengaruhi pandangan atau opini publik perihal kedua game tersebut, seperti yang dikatakan Sobur dalam bukunya analisis teks media bahwa sebuah media yang dikelola mandiri ataupun kolektif memiliki tujuan untuk membangun opini publik, disamping tujuan awalnya sebagai penyampai berita serta pemberi gambaran umum mengenai banyak hal (Sobur, 2009). Berdasarkan uraian tersebut dapat diambil makna bahwa sebuah media yang didalamnya berisi kontenkonten ditujukan untuk merekonstruksi sebuah pandangan umum mengenai sesuatu hal, sehingga dapat dikatakan bahwa selalu ada maksud tertentu disaat mengeluarkan konten yang ada baik itu berisi hal baik ataupun buruk.

Hal ini juga, berhubungan dengan konten-konten mengenai FF dan PUBG yang ada di dalam media tiktok. Jadi, dengan setiap konten dari media itu memiliki makna atau ideologi yang dibawa yang berasal dari pembuat kontennya baik itu menjelekkan game FF atau Game PUBG, dengan latar belakang seperti demikian penelitian ini arahkan untuk membedah dan mendeskripsikan bagaimana konten di media tiktok mengonstruksi sebuah makna mengenai Game FF dan PUBG dengan menggunakan analisis wacana kritis Norman Fairclough.

Jadi, didalam penelitian kali ini peneliti menggunakan analisis wacana untuk membedah fakta yang ada didalam media tersebut, dikarenakan analisis wacana sangat populer digunakan dalam wilayah riset media dan komunikasi tidak hanya itu analisis wacana memfokusikan pada bagaimana media merepresentasikan dan mem-framing teks yang ada di media. Selanjutnya mengenai analisis wacana kritis atau CDA (Critical Discourse Analysis) merupakan sebuah metodologi dalam paradigma kritis, yang mana dalam hal ini media dianggap sebagai saluran yang tidak netral dan bebas, serta media dimiliki oleh kelompok-kelompok tertentu dan bisa mendominasi kelompok lainnya yang dapat dikatakan kecil atau tidak dominan (Eriyanto, 2001)

Mengenai Analisis wacana kritis Norman Faircluogh merupakan sebuah metode yang apabila ingin memahami wacana (teks/naskah) kita tidak dapat melepaskan dari konteks, yang mana supaya menemukan sebuah realitas dibalik teks kita harus melakukan penelusuran atas konteks produksi teks, konsumsi teks, dan aspek sosial budaya yang mempengaruhi pembuatan teks (Hamad, 2004) Sistem dari CDA Norman Fairclough bisa dilihat pada gambar di bawah ini.

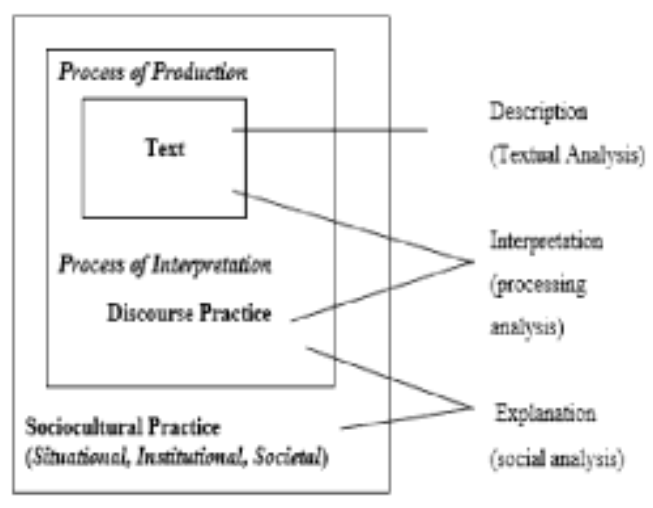

Gambar 1.

Sumber: ReserachGate.net 
Berdasarkan gambar diatas dapat diketahui bahwa analisis wacana kritis Norman Fairclough memberikan 3 tahap proses analisis yang berbeda, yaitu dimulai dengan tahap deskripsi, merupakan tahap dimana analisis dilakukan kepada teks pada bagian kohesi, tata bahasa, lalu diksi., tahap selanjutnya adalah interpretasi, tahap ini dimulai dengan melakukan analisis pada bagian produksi teks, penyebaran serta konsumsi teks., tahap terakhir adalah eksplanasi digunakan untuk analisis pada ranah sosiokultural dengan cakupan situasional, lalu institusional, dan sosial secara keseluruhan.

\section{METODE PENELITIAN}

Metode yang digunakan dalam penelitian kali ini adalah kualitatif diskriptif, menurut neuman penelitian kualitatif deskriptif adalah penelitian yang memiliki tujuan memberikan gambaran dengan menggunakan kata-kata dan angka serta untuk menyajikan persoalan, klasifikasi jenis, atau garis besar tahapan guna menjawab pertanyaan seperti siapa, kapan, dimana, dan bagaiamana.(Neuman, 2015), sedangkan menurut sugiyono penelitian kualitatif deskriptif merupakan penelitian dengan tujuan mendapatkan data teks dan angka yang akan dipaparkan secara hollistik.(Sugiyono, 2015)., dimana menurut Djajsudarma metode kualitatif merupakan prosedur yang menghasillkan data secara deskriptif baik lisan maupun tulis yang berkembang atau ada di (Djadjasudarma, 1993). Jadi, nanti data-data yang sudah terkumpul melalui analisis teks wacana akan disajikan secara deskriptif secara sistematis dan faktual dan apa adanya dalam artian tidak melihat mengenai benar atau salah mengenai fenomenafenomena yang dikaji.

Metode yang digunakan untuk mengumpulkan data adalah Simak catat yaitu sebuah metode yang mana peneliti memulai penelitian dengan memilah data-data yang sesuai dengan target dan mencatatnya untuk dibedah, sesuai dengan yang disampaikan Sudaryanto, mengungkapkan bahwa metode simak digunakan teknik dasar sadap, simak libat cakap, simak bebas libat cakap, rekam dan catat (Sudaryanto, 2015). Sedangkan menurut Mahsun Teknik simak ini adalah sebuah tekni pencarian data yang tidak hanya menyimak dalam artian lisan, melainkan data-data non-lisan (tertulis) (Mahsun, 2005). Dalam penelitian kali ini teknik simak catat yang digunakan dengan tahapan sebagai berikut: Pertama, Penulis mencari dan menandai konten di media tiktok yang berhubungan dengan game FF \& PUBG, Kedua. Mencatat temuan konten di media tiktok yang berhubungan dengan game FF \& PUBG, Ketiga. Menganalisis Teks/Video dari konten tersebut dari sudut pandang linguistik, yaitu penafsiran, penulis menganalisis proses produksi dan interpretasi teks; dan memaparkan serta menjelaskan bahwa konten tersebut berisi ejekan terhadap game FF atau kepada Game PUBG.

\section{HASIL DAN PEMBAHASAN}

Manusia merupakan sebuah makhluk sosial dimana tidak bisa untuk hidup sendirian di dalam dunia ini. Dengan kata lain, setiap kegiatan yang dilakukan memiliki tujuan di dalamnya untuk menunjukkan apa kebutuhannya kepada manusia yang lainnya begitu pula sebaliknya. Sehingga banyak terjadi sebuah hubungan-hubungan yang bisa menguntungkan satu sama lain ataupun bisa juga merugikan salah satunya. Dalam penelitian ini lebih ditekankan kepada sebuah pernyataan atau pendapat yang dibuat dan dibungkus menjadi video ataupun teks oleh salah satu individu melalui akun media tiktok miliknya.

Jadi, pada dasarnya penelitian ini hendak mendiskripsikan masing-masing konten yang berisi pernyataan atau pendapat mengenai game PUBG dan FF hendak diarahkan untuk mengejek atau hendak memuji dari salah satu game yang sedang booming 
tersebut. Dari sini peneliti mengambil beberapa konten dari Tiktok yang berkaitan dengan target tadi, lebih tepatnya peneliti akan mengambil 6 konten dari Tiktok untuk dibedah melalui analisis wacana kritis Norman Fairclough. Berikut nama akun dari masing-masing pembuat Konten:

Tabel 1.

\begin{tabular}{clll}
\hline No & \multicolumn{1}{c}{ Nama akun } & Tanggal Upload & \multicolumn{1}{c}{ Bentuk Konten } \\
\hline 1 & @Syahrul Firman Syah & $03-09-2020$ & Video, Audio, dan Teks \\
\hline 2 & @R4J4 KODOK & $28-07-2020$ & Video, Audio, dan Teks \\
\hline 3 & @EDWIN & $11-10-2020$ & Video, dan Audio \\
\hline 4 & @I'm Restu & $21-10-2020$ & Video, Audio, dan Teks \\
\hline 5 & @Leon & $15-10-2020$ & Video, Audio, dan Teks \\
\hline 6 & @MTM Sultan & $14-10-2020$ & Video, Audio, dan Teks
\end{tabular}

\section{Analisis Deskripsi}

Analisis yang pertama ini mengenai teks atau bahasa teks yang mana berhubungan dengan kosakata, diksi, ungkapan eufimistik (ungkapan yang dihaluskan), selain itu juga tata bahasa juga perlu ditelaah juga supaya mendapatkan informasi yang sepenuhnya dari konten yang sedang diteliti dan mendapatkan makna di dalamnya.

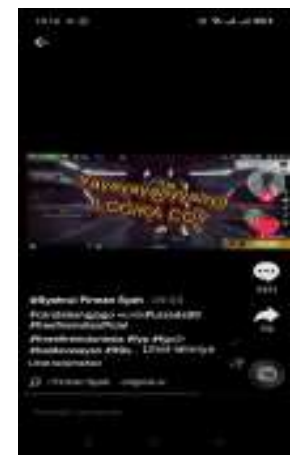

Gambar 2

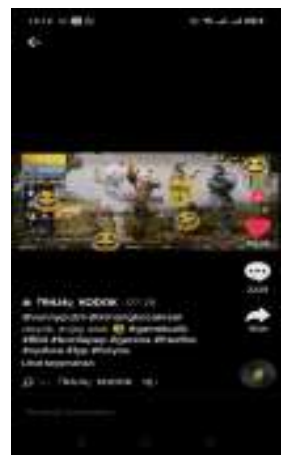

Gambar 3

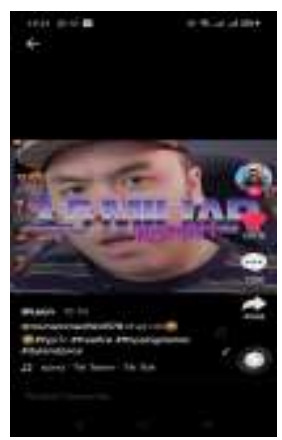

Gambar 7

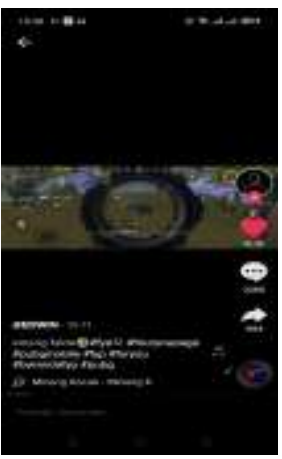

Gambar 4

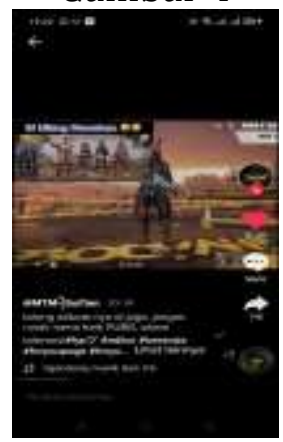

Gambar 8

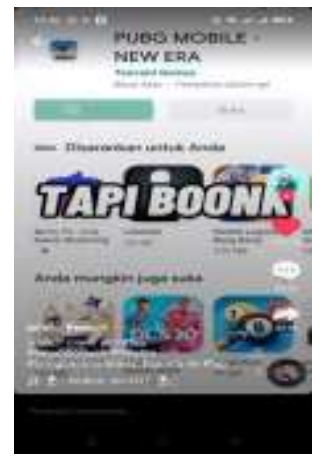

Gambar 5

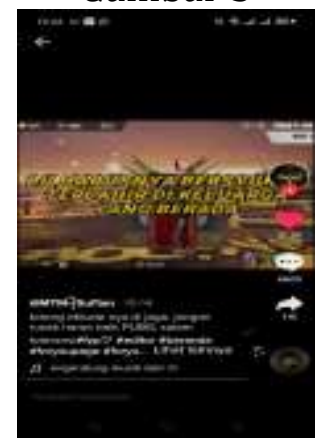

Gambar 9

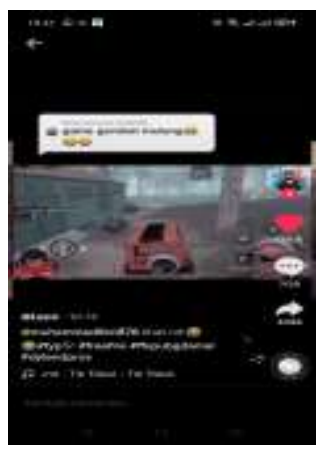

Gambar 6

Pada data ke-1 konten dari @Syahrul Firman Syah, disini pembuat konten menggunakan latar video di Beranda game $\mathrm{FF}$ dengan juga menggunakan audio yang mana menjelaskan tentang pendapat yang dia dengar mengenai FF yaitu "wkwkwkwk, FF Cuma 500 jt, PUBG dok bro 1,2 M anjay", tanggapanya adalah "boleh juga lu, lu liat liat lagi trending Youtube, sekarang isinya apa aja yang trending ha, FF sama Mobile Legend, game lu kemana bro, paling Cuma 1,2 dok dan itu Cuma Youtuber gede dok, yang lain kemana bro kok sepi seh, kata 1,2 M tapi kok gak ada, yayayay LOGIKA Coy". 
Pembuat konten selain menggunakan audio juga menuliskan teks dan menambahkannya di dalam video yang dia buat. Dilihat dari tanggapan awal terdapat ungkapan yang bisa dikatagorikan eufimistik yaitu "lu liat liat lagi trending youtube, sekarang isinya apa aja" disitu dapat diketahui bahwa pembuat konten mencoba membalas pernyataan diawal dengan menunjukkan realitinya di YT meskipun pemilihan diksi yang dipakai terlihat bahwa ingin menunjukkan game FF ini lebih baik daripada game PUBG yaitu dengan adanya kata "LOGIKA coy " pemilihan diksi logika coy itu menunjjukan bahwa jelas-jelas yang sedang trend itu game FF bukan game PUBG.

Apalagi jika kita mengetahui bahasa media bahwa sebuah kata ataupun kalimat yang dalam penulisannya itu di CAPSLOCK (diperbesar) semua mendakan bahwa orang tersebut sedang kesal atau marah dalam mengetik kata/kalimat tersebut. Melalui konten tersebut, pembuat konten ingin mengarahkan opini dari pemirsa/penonton bahwa Pernyataan yang mengejek FF yaitu "FF Cuma 500 jt pemain" ditangkis dengan fakta yang disampaikan diatas, selain itu juga memberikan ejekan kembali kepada game PUBG yang dibilang lebih sepi daripada game FF.

Pada data ke-2 konten dari @R4J4 KODOK, Pembuat konten ini sama yaitu video, audio, dan teks dengan latar video yang ditampilkan game PUBG di beranda game lebih tepatnya di lobby squad fight. Disini pembuat konten menggunakan design teks yang menarik dengan awalan sebuah pertanyaan kepada sesama anggota squad (teman yang ikut bermain, dalam hal ini maksimal 4 orang) yaitu "DJ, DJ apa yang paling lu suka?", masing-masing anggota team menjawab mulai dari Doyok "DJ Marshmello", lalu dilanjutkan oleh Vunny "Alan Walker", terakhir bang Momon "DJ Give bundle Alok Om".

Mungkin dari setiap pernyataan yang disampaikan mulai dari tata bahasa, atauapun pemilihan diksi, tidak ada yang seperti mengarah kepada mengejek ataupun memuji game FF. Tetapi jika melihat lebih jauh bahwa kenapa di jawaban terakhir yaitu bang momon "DJ give Bundle Alok Om", padahal Dj yang ada itu DJ Alok bukan Dj give bundle alok, disinilah letak dari satire ataupun ejekan dari pembuat konten. Jadi, terdapat sebuah korelasi antara pernyataan bang momon itu dengan game FF yang mana itu berkaitan dengan ejekan atau satire yang sering diterima oleh player dari game FF yaitu "Give Bundle Alok".

Jadi, Give bundle alok disini adalah kebiasaan dari player FF yang mana meminta kepada orang yang lebih punya dalam hal diamond (diamond $=$ uang asli di dalam game FF), meminta bundle (kostum di dalam game FF) yang bernama Alok itu. Jadi, dapat di ibaratkan bahwa orang yang mengucapkan give bundle Alok sama dengan mengemis untuk mendapatkan bundle Alok dimana memang harganya luar biasa mahal apabila diuangkan kurang lebih 1 juta-an.

Sehingga orang/player yang tidak mampu untuk menjangkaunya hanya bisa meminta melalui youtuber-youtuber FF yang memang kaya seperti Dyland Pros, Kemaz Pake $\mathrm{Z}$ dan lain-lain, layaknya pengemis yang meminta-minta. Dari situ terlihat jelas bahwa arah dari konten yang dibuat oleh akun R4J4 KODOK ini adalah untuk mengejek kepada pihak game FF, memang apabila di lihat awal konten hanya menunjukkan mengenai DJ yang disukai masing-masing orang, namun di saat itu juga digunakan untuk menemuka celah supaya bisa untuk mengejek game FF yaitu melalui kalimat "Give Bundle Alok Om".

Pada data ke-3 konten dari @EDWIN, disini pembuat konten hanya menggunakan latar belakang gameplay dari PUBG dengan menggunakan Audio saja tanpa teks. Dalam video ini pembuat konten mencoba menjelaskan bahwa setiap pernyataan ejekan dari FF kepada PUBG seperti "PUBG game Haram" dan "PUBG game mulung" tidak benar. Seperti pernyataan "Game kami haram dimananya?, lalu game mulung apanya, orang inventory kami aja harganya puluhan juta bahkan ada yang sudah ratusan juta", disini 
dia mencoba menerangkan bahwa tuduhan yang selama ini orang FF berikan itu salah dan tidak benar.

Setelah itu, tidak berhenti di penyampain belaan itu audio selanjutnya adalah balasan atau bisa dibilang counternya seperti "coba game FF gaada pintu kami bilang, kan memang faktanya ga ada pintu, lalu game FF game bocil, kan memang benar juga kebanyakan player game FF bocil (bocah cilik), plus game FF kami bilang burik (buruk/jelek), kan memang burik game kalian itu, seperti itu kan memang faktanya". Counternya menurutnya adalah fakta sehingga dia merasa jika menyebutkan itu tidak salah dan memang tidak bisa disalahkan.

Dari beberapa penjabaran diatas dapat diketahui bahwa konten dari @EDWIN ini, memang mengarahkan opini pemirsa kepada fakta bahwa game PUBG itu tidak haram dan tidak bisa disebut game mulung, sedangkan game FF jelas sebagai game yang gaada pintu, game bocil serta game yang dapat digolongkan game burik.

Pada data ke-4 konten dari @I'm Restu, disini pembuat konten menggunakan latar video gabungan mulai dari layar hitam, beranda Playstore sampai gameplay FF. Awal video adalah menunjukkan bahwa saat bateri HP 100\%, memiliki kuota yang full dan jaringan 4G maka akan diarahkan untuk main game yaitu FF. Namun, di tengah editan transisi video dari layar hitam ke beranda playstore disitu terjadi sebuah niatan untuk mengejek ditambah kalimat "Tapi Boong".

Transisi itu menunjukan pembuat konten ingin mendowload game PUBG di saat baterai hp sudah full serta kuota full dan jaringan 4G, tapi diberikan teks kalimat berupa "tapi boong" dilanjutkan video gameplaye dari game FF, sehingga menunjukkan tidak mungkin dia akan main PUBG melainkan di akan main game FF. Jadi, penggiringan opini yang dilakukan ini mulai sejak transisi video pertama hingga terkakhir ditambah dengan narasi teks-teks yang menuju kesitu yaitu, mencoba untuk menghilangkan game PUBG dengan lebih baik memainkan game FF.

Pada data ke-5 konten dari @Leon, pembuat konten memulai dengan sebuah video yang menggunakan fitur balas dari Tiktok, konsepnya itu di saat salah satu pemirsa ada yang komen di konten tersebut lalu di balas/forward dengan ditunjukkan video baru dengan komenan pemirsa tadi ditambahkan di dalamnya. Meneruskan yang tadi jadi pemirsa ada yang komen dengan kalimat "game gembel mulung" dijawab dengan video berlatar belakang gameplay PUBG dimana di dalamnya terdapat percakapan bahwa "abis 100 jt dapat apa?", disini artinya bahwa mana bisa game PUBG disebut game gembel mulung orang seketika membeli inventory itu bisa 100 jt-an ditambahkan kalimat "anjay sultan" disini sangat ingin menunjukkan bahwa game PUBG adalah game yang mahal.

Tidak selesai sampai disitu pembuat konten menambahkan video lain yang mana bertujuan untuk meng-counter video sebelumnya dengan latar belakang youtuber besar FF yaitu Dyland Pros. Bentuk dari videonya adalah di edit dengan teks yang menarik yang mana ingin menekankan dari perkataan Dyland Pros yaitu "25 juta diamond, kalau dari perhitungan kalkulator itu sebesar 3,5 milyar rupiah" setelah itu ditambhkan kalimat yang bisa dikatagrikan penguat yaitu "ini baru sultan". Dari sini jelas bahwa arah opini adalah bahwa game FF lebih sultan (kaya) daripada game PUBG dengan perbandingan dua video yang sudah diedit sedemikian rupa.

Pada data ke-6, konten dari @MTM sultan, pembuat konten menggunakan fitur duet pada tiktok yaitu fitur yang bisa menggabungkan beberapa video, disini terdapat 2 video yang mana datu berlatar belakang beranda game PUBG lalu satunya berlatar belakang beranda game FF, jadi pembuat konten disini bertujuan untuk menduetkan video sebelumnya dengan video yang dia buat yang mana masing-masing video memiliki makna masing-masing. Video pertama ini memiliki makna memberikan balasan jawaban kepada pernyataan "Jelek baju PUBG", dengan 
pernyataan yang tanpa telaah jauh sudah sangat mengejek yaitu dengan pernyataan "Tahu ga sih!! Kalau harga satu baju di PUBG itu seharga ginjal lu, iri bilang bawahan!".

Terlihat bahwa counter yang diberikan jelas sekali untuk merendahkan game FF, selanjutnya game kedua bisa dikatakan counter juga namun juga tidak dibilang counter karena disini video kedua ini pembuat konten hanya memberikan pesan-pesan yang mana tidak ada unsur mengejek seperti pernyataan ini "Tolong attitude dijaga", lalu "ingat di atas langit masih ada langit" terakhir ditutup dengan pernyataan "Salam Toleransi dari Player FF jaga selalu attitude". Pembuat konten jelas membawa opini dari pemirsa untuk berhenti saling menjelekan salah satu game dan menjaga adab melalui video counter yang dibuat olehnya.

\section{Analisis Interpretasi}

Tahap analisis selanjutnya adalah interpretasi, tahap ini adalah dimana peneliti mencoba menganalisis kepada bagian pemrosesan wacana, yaitu proses dari editor (pembuat konten) dalam mengupload konten atau penyebaran wacana di dalamnya, lalu profil dari editor, serta cara editor memproduksi teks.

Pada akun ke-1 @Syahrul Firman Syah, Meng-upload konten miliknya yang dijadikan data pertama pada tanggal 03-09-2020, lalu akun ini memiliki 43 konten yang mana keseluruhan konten akun ini memang berisi video yang diedit dan bersinggungan dengan game FF. Setelah itu, cara pembuat konten ini meng-edit dari videonya tersebut secara halus, dalam artian pemilihan diksi dari awal tidak ada yang kasar atau tidak sopan, dan juga makna dari konten tersebut juga mudah diterima dikarenkan pembuat konten tidak menggunakan kata yang bias makna ataupun kata yang ambigu.

Akun ke-2 yaitu @R4J4 KODOK, meng-upload kontennya pada tanggal 28-07-2020, secara kurun waktu viral dari editor-editor pembuat konten dengan isi konten yang berhubungan dengan game FF ataupun PUBG adalah sejak awal tahun 2020 sampai sekarang masih banyak orang-orang yang membuat konten seperti itu. Akun ini memiliki 293 konten yang kebanyakan video editan yang berhubungan dengan game PUBG dengan isian dari kontennya adalah mengejek ataupun membalas ejekan dari game FF.

Setelah itu, cara akun ini membentuk dari kontennya untuk mengejek game FF melalui sebuah konsep bercanda dan teka-teki artinya pembuat konten mengarahkan videonya itu supaya makna aslinya tidak terlalu terlihat oleh orang-orang yang awam akan kedua game yang booming itu, namun jika dilihat oleh para penikmat/player dari masing-masing game maka makna asli langsung terlihat bahwa pembuat konten ini ingin mengejek game FF dengan cara candaan yang memang berkaitan dengan Ejekan dari game FF yaitu "Give Bundle Alok"

Akun ke-3 yaitu @EDWIN , meng-upload videonya pada tanggal 11-10-2020 dimana ini merupakan konten yang masih baru dikarenakan belum ada satu bulan di dalam tiktok. Akun ini memiliki 83 konten dimana setiap kontennya hampir membahas mengenai PUBG yang dikaitkan dengan ejekan terhadap game FF. Cara akun ini membuat kontennya cukup sederhana hanya sebuah gameplay lalu diberikan backsound berupa suara orang yang sedang menjelaskan bahwa seluruh ejekan game FF kepada game PUBG tidak benar sedangkan pernyataan game PUBG kepada game FF itu memang fakta jadi tidak salah bagi game PUBG membicarakan hal demikian kepada game FF, contohnya seperti "Game FF tidak ada pintu".

Akun ke-4 yaitu @I'm Restu, meng-upload kontennya pada tanggal 21-10-2020, video ini juga masih baru di dalam tiktok. Akun ini memiliki 37 konten yang mana kebanyakan kontennya berisi gameplay dari FF, namun tidak banyak yang membahas game PUBG atau mengejek game PUBG. Cara pembuat konten meng-edit kontennya ini 
dengan sangat menarik yaitu mulai dengan sebuah gabungan video dengan sebuah audio yang jelas ditambah teks yang menjadikan makna yang ingin disampaikan semakin jelas diterima, bahkan orang awam sekalipun tahu bahwa konten ini memiliki maksud untuk mengejek game PUBG.

Akun ke-5 yaitu @Leon, meng-upload konten ini pada tanggal 15-10-2020 masih tergolong video baru dikarenakan masuk dalam bulan 10 atau Oktober. Akun ini memiliki 45 konten yang kebanyakan memakai latar belakang FF di dalamnya setiap kontennya. Pembuat konten membawa sebuah konsep balas kepada konten yang dijadikan data-5 maksudnya adalah video yang dibuat oleh akun Leon ini adalah untuk menjawab atau membalas video lain yang mana sedang mengejek game $\mathrm{FF}$, dan digabungkan menjadi 1 konten yang menarik. Selain itu, penyampaian makna yang ada sangat mudah ditangkap oleh orang awam apalagi oleh orang yang menekuni game $\mathrm{FF}$ ataupun PUBG.

Akun ke-6 yaitu @MTM Sultan, meng-upload kontennya pada tanggal 14-10-2020, sama dengan beberapa konten diatas video ini juga merupakan masih baru di dalam tiktok. Akun ini memiliki 293 yang hampir semuanya mengenai FF, namun tidak juga membawa atau mengejek game lain. Cara pembuat konten membawa arah makna yang ingin disampaikan terkesan cukup simple dikarenakan hanya berupa video yang diisi dengan teks tanpa adanya audio, namun sangat mudah dipahami oleh setiap orang yang melihat dan maknanya sendiri juga mudah ditemukan didalamnya atau bisa dibilang makna yang disampaikan secara tersurat.

\section{Analisis Ekplanasi}

Tahap terakhir ini merupakan sebuah analisis kepada aspek yang sosial artinya bahwa keadaan sosial yang ada di luar masyarakat/individu juga memengaruhi masingmasing dari mereka dalam merangkai atau mengkonstruk sebuah wacana. Selain itu, juga sebuah wacana yang sudah dikonstruk oleh individu ataupun kelompok juga dapat mempengaruhi dunia sosial secara keseluruhan apabila wacana yang dibuatnya disebarkan dan dikonsumsi banyak orang.

Dalam analisis ini memakai sebuah tingkat dalam proses analisisnya, yaitu mulai dari tingkat situasional, institusional dan sosial, yang mana masing-masing tingkatan itu mempengaruhi orang dan wacana yang akan dibuatnya seperti yang sudah disebutkan diatas. Tingkat situasional ini berhubungan dengan produksi dan konteks situasi yang mempengaruhi pembuatan wacana, lalu tingkat institusional merupakan adanya sebuah pengaruh yang diberikan oleh institusi terhadap pembuat konten (pembuat wacana) ataupun wacana/pendapat yang akan buat, terakhir adalah tingkat sosial yaitu sebuah pengaruh yang akan datang dari ruang yang lebib makro (luas) seperti sistem politik, sistem ekonomi, ataupun sosial budaya yang ada di masyarakat.

Dalam ke-6 data konten tiktok yang diangkat dalam penelitian kali ini tingkat situasional dan sosial dapat ditemukan, kecuali tingkat institusional dikarenakan dari penelitian tidak menterkaitkan dengan institusi manapun baik itu Tencent (perusahaan pencipta PUBG) ataupun garena (Perusahaan pencipta FF). Jadi, situasionalnya disini adalah keadaan/situasi yang mempengaruhi dari pembuat konten di dalam proses produksi konten/wacana sehingga sangat memungkinkan masing-masing konten yang dibuat itu tidak murni dari pembuatn konten saja artinya ada pengaruh keadaan yang juga membentuk konten yang sudah dibuat.

Selanjutnya dalam tingkat sosial, bahwa jelas dari setiap pembuat konten pasti dipengaruhi oleh kondisi sosial-budaya yang ada dalam lingkungan dari pembuat konten. Namun efek yang terjadi juga berkebalikan yaitu di saat konten yang ada itu sudah terbentuk dan mulai disebarkan di media dalam hal ini tiktok maka jelas akan 
dikonsumsi secara bebas oleh khalayak umum dan bisa mempengaruhi juga pandangan mereka mengenai wacana yang sedang diangkat oleh pembuat konten.

\section{KESIMPULAN}

Pada akhirnya penggunaan analisis wacana kritis dengan metode Norman Fairclough adalah untuk menemukan makna dari sebuah wacana yang dilontarkan, selain itu dengan ini juga terlihat bahwa teks atau pernyataan yang ada didalam sebuah konten itu menjadi praktik sosial artinya melalui teks ataupun pernyataan bertujuan untuk mempengaruhi secara sosial yaitu membawa ke arah wacana yang diinginkan oleh pembuat konten. Dalam penelitian kali ini ditemukan memang masing-masing individu selaku pembuat konten atau penyebar wacana memang membawa masing-masing wacananya ke arah sosial maksudnya supaya mempengaruhi pandangan umum mengenai game FF dan PUBG karena ditemukan dari data diatas ada yang ingin menjelekkan nama game $\mathrm{FF}$, yang lain ada yang ingin menjelekkan nama game PUBG, serta ada juga yang mengarahkan wacananya supaya masing-masing player ini menjaga attitude/sikap dalam artian saling tidak menjelekkan satu sama lain.

\section{DAFTAR PUSTAKA}

Andri Arif Kustiawan, S.Pd., M. Or. , Andy Widhiya Bayu Utomo, S.Pd., M. O. (2019). JANGAN SUKA GAME ONLINE: PENGARUH GAME ONLINE DAN TINDAKAN PENCEGAHAN. CV.Ae Media Grafika. https://books.google.co.id/books?id=2HWDwAAQBAJ\&printsec=frontcover\&dq=dampak+buruk+game+online\&hl=id\&sa=X\&ved=2 ahUKEwibpLHGoYTuAhVb7HMBHax7Dg4Q6AEwAHoECAQQAg\#v=twopage\&q\&f=false

CNBC Indonesia. (2020, August 25). https://www.cnbcindonesia.com/tech/20200825104121-37181742/berapa-pengguna-aktif-tiktok-di-dunia-jangan-kaget-yah. Dipetik October 5, 2020, dari CNBC Indonesia: https://www.cnbcindonesia.com/tech/20200825104121-37181742/berapa-pengguna-aktif-tiktok-di-dunia-jangan-kaget-yah

Djadjasudarma, T. F. (1993). Metode linguistik: ancangan metode penelitian dan kajian. Eresco. https://books.google.co.id/books?id=bqRMHAAACAAJ\&dq=Metode+linguistik+ancangan+ metode+penelitian+dan+kajian\&hl=id\&sa=X\&ved=2ahUKEwjf_qn7lYTuAhXUTX0KHYl9Aw YQ6AEwAHoECAAQAQ

Eriyanto. (2001). Analisis Wacana; Pengantar Analisis Teks Media: Komunikasi. In LKiS Yogyakarta. LKiS Yogyakarta. https://books.google.co.id/books?id=68dVDwAAQBAJ\&printsec=frontcover\&dq=analisis+ wacana:+pengantar+analisis+teks+media\&hl=id\&sa=X\&ved=2ahUKEwjfr9efl4TuAhVC73M BHYn2CesQ6AEwAHoECAYQAg\#v=onepage\&q=analisis wacana\%3A pengantar analisis teks media\&f $\mathrm{f}$ false

FIM Jakarta. (2020). Gagasan Pemuda untuk Jakarta. Edukasi Karya Indonesia. https://books.google.co.id/books?id=apsGEAAAQBAJ\&pg=PA264\&dq=dampak+buruk+gam e+online\&hl=id\&sa=X\&ved=2ahUKEwibpLHGoYTuAhVb7HMBHax7Dg4QuwUwBnoECAYQ $\mathrm{Bw} \# \mathrm{v}=$ onepage $\& \mathrm{q}=$ dampak buruk game online $\& \mathrm{f}=\mathrm{false}$

Hamad, I. (2004). Konstruksi realitas politik dalam media massa: sebuah studi critical discourse analysis terhadap berita-berita politik. Yayasan Obor Indonesia. https://books.google.co.id/books?id=BkEB7gJQMLQC\&pg=PA31\&dq=Lebih+dekat+dengan + analisis+wacana+hamad\&hl=id\&sa=X\&ved=2ahUKEwiR_f_Ml4TuAhWaf30KHXntBiMQ6AE

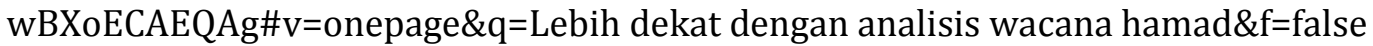

Mac Aditiawarman, D. (2019). Hoax dan Hate Speech di Dunia Maya. Lemabaga Kajian Aset Budaya Indonesia Tonggak Tuo. https://books.google.co.id/books?id=etXKDwAAQBAJ\&pg=PA80\&dq=ujaran+kebencian\&hl $=i d \& s a=X \& v e d=2 a h U K E w j H u a y k u 4 T u A h U O W X 0 K H V c J B a I Q 6 A E w A 3 o E C A U Q A g \# v=o n e p a g$ $\mathrm{e} \& \mathrm{q}=\mathrm{ujaran}$ kebencian\&f$=$ false

Mahsun. (2005). Metode Penelitian Bahasa: Tahap strategi, metode, dan tekhniknya. Raja 
Bayu Aji Sastra Jendra - Critical Discourse Analysis Fairclough on The Content of Game ....

Grafindo Persada.

Neuman, W. L. (2015). Social Research Methods: Qualitative and Quantitaive Approaches. PT. Indeks.

Rahadi, D. R. (2017). Perilaku Pengguna Dan Informasi Hoax Di Media Sosial. Jurnal Manajemen Dan Kewirausahaan, 5(1), 58-70. https://doi.org/10.26905/jmdk.v5i1.1342

Sugiyono. (2015). Metode Penelitian Kombinasi (Mixed Methods). Alfabeta.

Sudaryanto. (1993). Metode dan Aneka teknik analisis bahasa: pengantar penelitian wahana kebudayaan secara linguistis

Sobur, Alex. (2001). Analisis Teks Media: Suatu Pengantar Untuk Analisis wacana, analisis semiotik dan analisis framing. Remaja Rosdakarya

Ulfa, M. (2017). Effect of Addiction Online Game Center. Jom. Fisip, 4(1), 1-13. 
Bayu Aji Sastra Jendra - Critical Discourse Analysis Fairclough on The Content of Game .... 